\title{
Correction to: An in vitro and in vivo study of the combination of the heat shock protein inhibitor 17-allylamino-17- demethoxygeldanamycin and carboplatin in human ovarian cancer models
}

\author{
Udai Banerji ${ }^{1}$. Nivedita Sain ${ }^{2} \cdot$ Swee Y. Sharp ${ }^{1} \cdot$ Melanie Valenti ${ }^{1} \cdot$ Yasmin Asad $^{1} \cdot$ Ruth Ruddle $^{1} \cdot$ Florence Raynaud $^{1}$. \\ Michael Walton ${ }^{1}$. Suzanne A. Eccles ${ }^{1} \cdot$ Ian Judson ${ }^{1} \cdot$ Ann L. Jackman ${ }^{2} \cdot$ Paul Workman $^{1}$
}

Published online: 1 September 2018

(c) Springer-Verlag GmbH Germany, part of Springer Nature 2018

\section{Correction to: \\ Cancer Chemother Pharmacol (2008) 62:769-778 \\ https://doi.org/10.1007/s00280-007-0662-x}

The corresponding author of the original article has informed us of concerns about the immunoblots in Fig. 2 which were carried out in the collaborating laboratory of Professor Ann Jackman. The experiment has been replicated twice in the Workman laboratory and the findings remain the same. The authors have provided the original blots and the corrected version for Fig. 2 and this has been included in the latest online HTML and PDF versions of the article. The change does not affect the Figure Legend or main text of the article. The authors regret this error.

The original article can be found online at https://doi.org/10.1007/ s00280-007-0662-x.

Paul Workman

Paul.Workman@icr.ac.uk

1 Cancer Research UK Centre for Cancer Therapeutics,

Haddow Laboratories, The Institute of Cancer Research, 15

Cotswold Road, Sutton, Surrey SM2 5NG, UK

2 Section of Medicine, Haddow Laboratories, The Institute of Cancer Research, Sutton, UK 


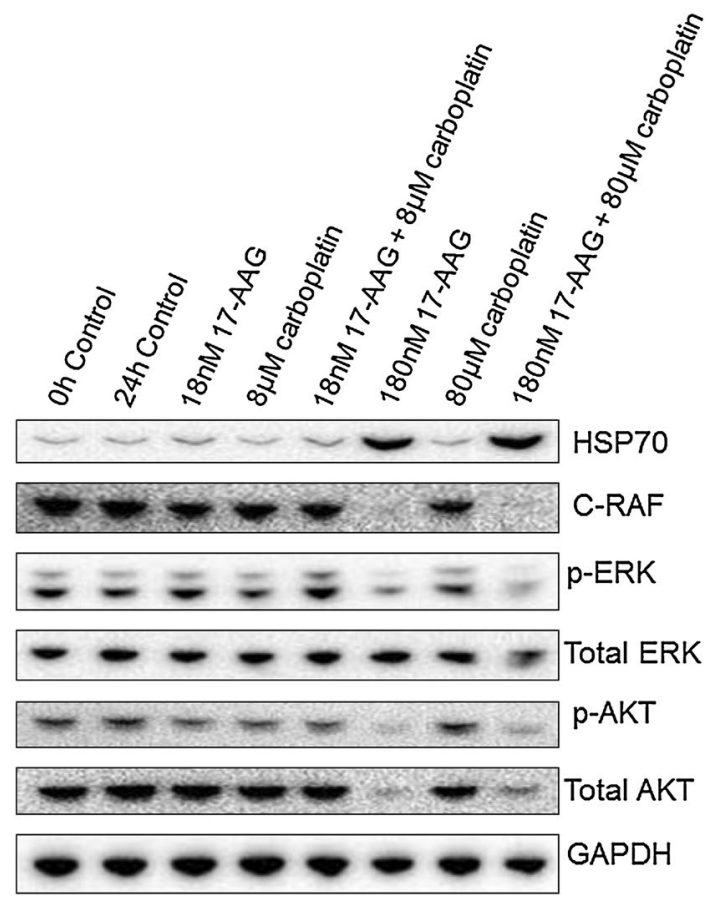

Fig. 2 Effects in A2780 human ovarian cancer cells of 17-AAG, carboplatin or the combination of both drugs on the expression HSP90 client proteins and the co-chaperone HSP70. Proteins were analyzed by western blotting with glyceraldehyde-3-phosphate dehydrogenase $(\mathrm{GAPDH})$ as the loading control. Cells exposed to control, $1 \times \mathrm{IC}_{50}$ and $10 \times \mathrm{IC}_{50}$ concentrations of both drugs as single agents and in combination. The $\mathrm{IC}_{50}$ values for 17-AAG and carboplatin were $18 \mathrm{nM}$ and $8 \mu \mathrm{M}$ respectively. Effects on client proteins C-RAF, p-AKT and AKT in addition to co-chaperone HSP70 and downstream signaling proteins p-ERK and ERK are shown. The experiment was repeated independently with similar results 